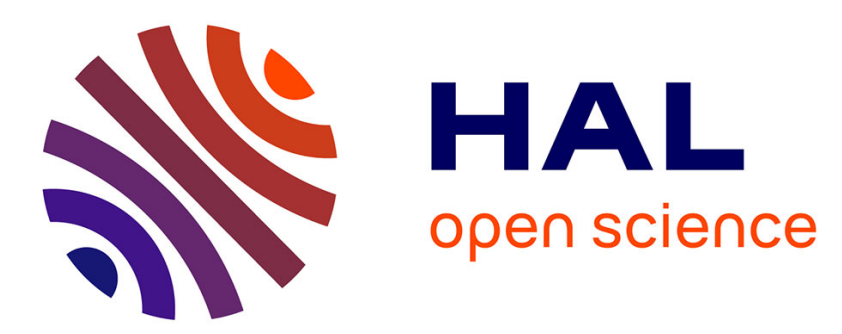

\title{
Back to Front: The Role of Seminars, Conferences and Workshops in the History of Economics
}

Béatrice Cherrier, Aurélien Saidi

\section{To cite this version:}

Béatrice Cherrier, Aurélien Saidi. Back to Front: The Role of Seminars, Conferences and Workshops in the History of Economics. Revue d'Economie Politique, 2021, 131, pp.609-635. 10.3917/redp.314.0005 . hal-03318670

\section{HAL Id: hal-03318670 \\ https://hal.science/hal-03318670}

Submitted on 4 Jan 2022

HAL is a multi-disciplinary open access archive for the deposit and dissemination of scientific research documents, whether they are published or not. The documents may come from teaching and research institutions in France or abroad, or from public or private research centers.
L'archive ouverte pluridisciplinaire HAL, est destinée au dépôt et à la diffusion de documents scientifiques de niveau recherche, publiés ou non, émanant des établissements d'enseignement et de recherche français ou étrangers, des laboratoires publics ou privés. 


\title{
The role of seminars, conferences and workshops in the history of economics ${ }^{1}$
}

\author{
Beatrice Cherrier \& Aurélien Saïdi \\ CNRS, ENSAE \& Ecole Polytechnique, IP Paris; Université Paris- Nanterre
}

\section{Introduction}

One element of economists' daily routine made salient by the 2020 coronavirus outbreak is the sheer amount of time organizing, traveling to and attending workshops, seminars and conferences. Part of this time was freed, part was spent online instead, offering a different kind of intellectual and social experience. These events belong to the fabric of academic life. The annual conference sponsored by the Allied Social Sciences Association (ASSA) and the American Economic Association (AEA) has been a focal point for US-based economists for more than a century, and their summers are often spent attending the fields summer schools organized by the National Bureau of Economic Research (NBER).

Accounts of how ideas were developed and disseminated often mention an important conference, workshop or seminar as a background. The methodology of economics, concepts of equilibrium, growth, interest rates and dynamics were debated in private gatherings including the Vienna circle, Menger's seminar or Keynes's Cambridge circus. A new international monetary and financial order was forged during the 3-weeks 1944 Bretton Woods conference. Neoliberalism emerged from the 1938 Walter Lippman colloquium and consolidated through annual Mont Pelerin conferences. Expected utility theory was both stabilized and destabilized during the Conférence sur le Risque, organized in Paris in 1952 by Maurice Allais. Decision theory, game-theoretic models, as well as all sorts of mathematical applications to micro and macroeconomics were dissected throughout a month-long annual Stanford summer workshop organized by the Institute for Mathematical Studies in Social Science (now Stanford Institute for Theoretical Economics) under the leadership of Mordecai Kurz since the 1970s. It took three Santa Fe seminars on The Economy as an Evolving Complex System in 1987, 1996 and 2001 to build a new field, complexity economics. Macroeconomic models have been debated in the US during regular meetings of the Brookings panel, of the Carnegie-Rochester conferences, and of NBER workshops. The Roy-Malinvaud seminar has long remained the reference for French economists, attracting many colleagues from all over the world. These are just a few examples.

While conferences, workshops and seminars are ubiquitous in the history of economics, historians have mostly treated them as sceneries rather than lenses to study science in action. A few exceptions include Aurélien Goutsmedt (2017), who uses the 1978 macroeconomics conference organized by the Federal Reserve Bank of Boston to contextualize Robert Lucas and Thomas Sargent's attack on Keynesian macroeconomics. Likewise, Till Düppe and Roy Weintraub (2014) locate the birth of a new scientific culture in economics as well as a new set of tools in the 1949 Activity Analysis conference organized by the Cowles Commission. They do not so much describe the conference in itself as use it as a frame to describe the epistemologies and common mindset of the various participants, as well as the communities

\footnotetext{
${ }^{1}$ Correspondence may be addressed to Beatrice Cherrier (beatrice.cherrier[a]ensae.fr) and Aurélien Saidi (aurelien.saidi[a]parisnanterre.fr). We are grateful to REP editors Tarik Tazdait, Bertrand Crettez and Cecile Couharde, to all participants in this project, to our referees, as well as to Roger Backhouse and Steven Medema for comments and suggestions, and Irwin Collier for providing very helpful material.
} 
they belonged to. Nor has the contribution of such events to the development, dominance and marginalization of research programs, social structures and professional cultures been extensively analyzed. Ross Emmett (2011) has investigated of the role played by the workshop system established by 1950s and 1960s Chicago economists in sharpening their tools and approaches. Elliott Ash, Daniel Chen and Sureh Naidu (2018) systematically analyzed the effect of Henry Manne's law and economics training program for US federal judges on criminal sentences. Emmanuel Monneau (2018) drew on the French séminaire Aftalion of the 1960s to explain how a seminar can act as a transitory academic device to socialize students into a new approach - here, heterodox economic theory - and help them build a career in the absence of devoted research centers and departments. The lack of more systematic investigation into how conferences, workshops and seminars shape the intellectual, institutional and cultural structures of economics is especially problematic given the recent interest in their possible contribution to gender and race imbalances in the profession. For instance, Pascaline Dupas, Alicia Sasser Modestino, Muriel Niederle and Justin Wolfers (2021) have recently established that women are asked more questions during US economic seminars, some more likely to be patronizing or hostile. Assessing the origins and consequences of such patterns however requires a qualitative understanding of the role played by such seminars in economics.

In these twin special issues of the Revue d'Economie Politique, we intend to turn what we will call SCoWs (for Seminars, Conferences and Workshops) into a full-fledged object of study. ${ }^{2}$ The central protagonists of articles are SCoWs held in Europe and in the United-States throughout the 20th century. Robert Dimand (2021, next vol.) surveys the organization and legacy of the summer research conferences organized by the Cowles Commission in Colorado Springs (USA) between 1935 and 1940. Ola Innset (2021, next vol) documents the social origins and interactions of participants to the founding 1947 conference of the Mont Pelerin Society, in Switzerland. There, 39 participants argued over the content of neoliberalism and sought common ground to root their advocacy of liberal policies. Peter Boettke, Alain Marciano and Solomon Stein (2021, next vol) dissect the workshops and conferences organized at the University of Virginia, Virginia Polytechnique Institute and George Mason University under the tutelage of James Buchanan in the 1950s to 1980s. Pedro Texeira (2021, this vol.) documents the rise, operation and dwindling of Columbia Labor Workshop established by Gary Becker and Jacob Mincer in the 1960s. A few years later, Elinor and Vincent Ostrom set up a Workshop in Political Theory and Policy at the University of Indiana. The Ostroms' reflexive crafting and governance of this atypical center is unpacked by Erwin Dekker and Pavel Kuchar (2021, this volume). By the end of the 1970s, the French EHESS and the NBER sponsored an International Seminar on Macroeconomics (ISoM) meant to bring together European and American scholars. Aurelien Goutsmedt, Mathieu Renault and Francesco Sergi (2021, this vol.) offer a quantitative and qualitative account of the changing networks produced by ISoM, which still operates. Finally, Nicolas Camilotto (2021, next vol) explores how young sociologist Diego Gambetta set up an interdisciplinary Seminar on Trust and Social Change at Cambridge in 1984. He explains how the seminar and resulting book managed to turn trust into a worthy topic for economists.

\footnotetext{
${ }^{2}$ It may seem problematic to use an acronym for our object throughout the paper. We do so, not just because "seminars, conferences and workshops" is a long expression, but also because part of our purpose is to characterize this object of study.
} 
By means of introduction to this volume, we use this set of case studies as well as some other examples to highlight salient characteristics of SCoWs. ${ }^{3}$ We first explain that tight classifications of SCoWs are hard to come up with, if only because their names and organization derive from a mix of traditions - the ecclesial origins of seminars, the craft analogies that the term workshop carries - contexts and contingencies. It is however possible to outline salient features and dimensions worth considering, ranging from frequency to location, and yoke these to a variety of purposes. We argue that SCoWs should not merely be understood as two-hours, 3 days or week-long span of time in which economists attend presentations and partake into scientific discussions. What happens upstream (for instance, grant applications, negotiations with sponsors, selection of location and speakers) and downstream (from after drinks and dinners to proceeding publication) are also key to understand their legacies. So are the institutional, social and symbolic webs in which intellectual exchanges are entangled.

We then detail two major functions of SCoWs. They can be viewed as construction sites where theories, concepts, but also tools and practices and even political programs are built through bringing in various intellectual and institutional resources. They can also be understood as weapons of mass dissemination, whereby such theories, tools practices, etc., are sent out, first, to students, then, to colleagues, opponents and institutions. SCOWs thus serve as devices to convince, to stabilize, to mainstream and marginalize, but also to challenge the existing intellectual and institutional structure of economics. Those processes involve the formation of networks and communities of like-minded scholars, even friends, but also the exclusion of others, and the development of age, institutional, class and gender hierarchies. These are channeled via how workshop and conferences' rules are set up or what food and drinks are offered for instance. We finally reflect on what may drive the persistence, visibility, or failures of workshops, seminars and conferences: leadership and entrepreneurship.

\section{What's our object and why study it?}

It is impossible to propose a neat classification of SCoWs, one in which each of these three categories would exhibit stable frequency, location and purpose characteristics. One reason is that how these events are called is often historically contingent. For instance, the International Seminar on Macroeconomics (ISoM) studied by Goustmedt, Renaud and Sergi (2021) was initially conceived as a "series of European conferences on Macroeconomic policy." Its name and organization were modeled on the NBER conferences that it was meant to emulate. The Ostrom workshop in Political Theory and Policy, whose name was chosen carefully, replaced a regular colloquium (Dekker and Kuchař 2021) The Columbia Labor Workshop described by Texeira (2021) was named after the Chicago workshop system it borrowed from. It could have equally been called a seminar. In his history of the Chicago workshop system, Ross Emmett (2011) shows how T.W. Schultz and D. Gale Johnson drew on the example of the conferences and seminars organized by the Cowles Commission, then located on site, as well as the social science "laboratories" of the Industrial Relations Center. At the department of economics, these events were originally called "research seminars," before they became "workshops" in the early 1950. Other terms encountered in this article include institute, meeting, forum, congress or symposium, study group or even club. In this, economics is nothing specific. One of the most famous scientific conferences was the one organized in 1927 by the International Solvay Institutes for Physics and Chemistry. Its subject was Electrons and Photons and it pitched the

\footnotetext{
${ }^{3}$ To avoid burdening the text with too many references, we don't refer to the articles published in each issue each time we draw from them. But unless otherwise referenced, all material on the Ostrom Workshop is taken from Dekker and Kuchař (volume), all material on the Columbia workshop from Texeira (this vol) and so forth.
} 
interpretations of uncertainty relations and quantum theory of Niels Bohr, Albert Einstein, Irwin Schröedinger and Albert de Broglie against one another. It was part of a series of events indifferently called, in French, "Congrès Solvay," "Conseils Solvay" or "Conférences Solvay"

\section{Origins}

Historical contingencies are however tangled with path dependencies. For both "workshops" and "seminars" have multi-century histories, some that point to distinct functions of these events. On the one hand, the seminar (Seminarium) is of ecclesiastical origin. Historian Herbert Adams (1884) defined it as "a nursery of theology and a training-school for seminary priests. The modern theological seminary has evolved from the mediaeval institution, and modern seminary-students, whether at school or at the university, are only modifications of the earlier types." He explained $(1884,64)$ how, in theology seminars themselves, preachers have become teachers and how 'the propaganda of religion prepared the way for the propaganda of science...it has evolved from a nursery of dogma into a laboratory of scientific truth."4 The transition from the ecclesiastical to the doctoral research seminar was nurtured by German humanities and social sciences in the 19th century, before being imported in the US (Fourcade 2009, 65; Adams 1884). These seminars were often associated with and held within libraries. They included the Berlin Statistical Seminary, opened in 1862 by Ernst Engel, as well as the Heidelberg Seminar of Political Economy run by Karl Knies. This combination of and tension between training and research, critical and propaganda purposes surface in several account of more contemporary economic seminars.

The history of the workshop is equally rooted in religion. Early workshops appeared in monasteries, but then secularized, Richard Sennett (2008, ch2) points. From medieval times to Renaissance and contemporary science, "the social history of craftmanship is in large part a story of the efforts of workshops to face or duck issues of authority and autonomy," he explains, and of individual and collective dynamics, he implies. Drawing on goldsmithing, he describes medieval workshops as sites where apprentices learned how to imitate the master, one that acted as a surrogate parent and derived her or, more often, his authority from the skills that he aimed to transfer through face-to-face interaction. Yet, he also documents how craft was dominated by a "collective agent," a set of people "glued together through work rituals," such as a guild. During the Renaissance, the master became an artist, with apprentices expected to help realize his vision. The workshop became more of a studio, one that embodied an individual's originality. This however made transfers of knowledge, in particular tacit knowledge, more difficult. This explain why some renaissance workshops, albeit successful, were short-lived Sennett takes the example of Stradivari. With the stabilization and codification of scientific knowledge, the development of laboratories, but also of rationalized models of labor, the "workshop" model entered the university. In the 1910s, for instance, Harvard theater professor G.P. Bakker established the 47 Workshop. Literature scholar Christopher Kempf (2020) interprets Bakker's craft analogy as a resistance against the rise of mass theater, as well as a way to challenge the distinction between manual and mental work and to reconcile utility and aesthetics. $^{5}$

\footnotetext{
${ }^{4} \mathrm{We}$ are grateful to Irwin Collier for pointing us to Adams's analysis

${ }^{5}$ Enforcing technical standards while enhancing the craftman's creativity, reconciling "Beauty with Usefulness" against industrialization was the purpose of the American Arts and Crafts movement more largely (Kempf 2020).
} 
Several histories in our volumes point to the uses of craft analogies in the development of workshops. Dekker and Kuchař document how articulate the Ostroms were in "calling this place workshop instead of a center was because of working with Paul and understanding what artisanship was... the whole idea of artisans and apprentices and the structure of a good workshop really made an impression on us." 'Paul' was Paul Goodman, a master carpenter who taught them how to make furniture. They intended their workshop as "a family" in which all could discuss and contribute, being "on equal footing." Yet, Dekker and Kuchař remarked, they were nonetheless considered as the master craftsmen. At Chicago, around 1950, labor economist $\mathrm{H}$. Gregg Lewis defended the need for a reorganization of graduate education in a memo to Schultz that emphasized the need "for training...graduate students as scientific craftsmen" (Emmett 2011, 102). Quoting from a proposal by NBER business cycle economist Arthur Burns, he explained that this required that each professor "will have his own laboratory" so that students" individual assignments "fit together." Such need to coordinate students' work toward a greater collective objective was the motive behind Harry G. Johnson's setting up the first typical Chicago workshop. Chicago economists also considered the workshop system as a way "to make the use of the tools [of analysis] almost a second nature, and then think of ways to apply them to common issues that they had not been used on before" (quoted in Emmett 2011, 107). ${ }^{6}$ Notions of apprenticeship and mastery are pervasive in these narratives. Given that Gary Becker was probably influenced by his Chicago days when he co-developed the Columbia labor workshop with Jacob Mincer in the 1960s, it is not surprising that he later characterized it as a "student apprenticeship" (Texeira 2021). That same wording is also found in Buchanan's 1960 plans to reform graduate education at Virginia Polytech Institute (Boettke, Marciano and Stein 2021).

In this short historical discussion, we proceeded from designations to characteristics. Going the other way, aka looking at intellectual and scientific gatherings or meetings, expands the range of prehistories. However, it also blurs boundaries between science and advocacy, public and private spheres, social, cultural, entertainment and intellectual purposes. These tensions still exist. Science was part of the topics discussed in $18^{\text {th }}$ century salons, so that Johan Heilbron (2006) traced the birth of sociology to both institutions. Political Economy as a set of topics, then methods, was articulated throughout the $19^{\mathrm{Th}}$ and early $20^{\mathrm{Th}}$ century at the Political Economy Club of London, founded in 1821. Initially formed to support the principles of free trade, it quickly became a "vital, sometimes acrimonious, center for debate," Henderson (1983, 151) explained, citing the diary of an early participant: "we early found it necessary to cease coming to any conclusions." The club was a closed one, with a membership limited to 30 that included David Ricardo, JS Mill, Francis Edgeworth, Nassau Senior or WT Thornton. They met on the first Monday of each month to discuss topics proposed by a rotating selection of 3 members. It initially forbade the use of written notes but this later changed. This organization was emulated in 1884 by those American economists who felt that they needed, in the words of J.L. Laughlin, "an organization...for conference, for discussion, for mutual stimulus, for encouragement of the study in the proper scientific spirit by others" (Coats 1961, 627). The club was short-lived, due to internal disagreement on the political or scientific nature of the endeavor. It was informal and meetings were organized throughout the country in participants' homes. Some of those early clubs may thus be considered as early exemples of economics SCoWs.

\footnotetext{
${ }^{6}$ Deidre McCloskey $(1992,243)$ shares a similar anecdote about how Harvard's Alexander Gerschenkron set up a economic history workshop in the 1960s: "the work of scholarship was similar to the work one in a motorcycle repair shop, - the "bench science" of a laboratory," she remembers
} 


\section{Purposes and characteristics}

Though scientific conferences, and in particular, seminars and workshops are more common than they were in economics a century ago, a chronological reading of case studies does not point to radical transformation in their purposes and characteristics. The object is not new. The ASSA had held annual meetings since 1876, and the just-created AEA organized its first annual meeting under its umbrella in 1885. The Cowles Commission began organizing American and European annual meetings, summer conferences and seminars as soon as it was established in December 1930. If there are more SCoWs to attend every year, it is not because they operate differently. It rather reflects the institutionalization of economics at a more granular level (geographically and in terms of applied fields), and most importantly the sharp decrease in transportation, communication and reproduction costs (see Backhouse 1997). Archives from the 1930s to 1980s are littered with complex and changing travel plans, with economists often planning "tours" when having to travel overseas, coupling conferences, seminars and visiting stints. What these case studies together highlight, rather, is the diversity of intended purposes underpinning the organization of SCoWs, thus how diversly they have contributed to shape the structure, content and dynamics of the discipline. The varied aims with which SCoWs are organized can be captured through documenting their characteristics, in particular the combination of location, time and frequency.

Some locations were purposively chosen as central, to raise the number of attendants, outreach and visibility (Paris in the case of the International Seminar of Macroeconomics, the mix of Boston, Chicago, San Francesco for annual ASSA conferences, NBER workshops), others were deliberately set up in remote areas to invite undisturbed and sustained exchanges (Mont Pelerin in Switzerland; Colorado Springs for the Cowles Summer Research Conferences). Those events meant at bringing scholars in were usually held in the same location, while dissemination required rotating locations. Though often conceived as events, seminars and workshops sometimes acquired some permanence, even materiality. For instance, the Séminaire Aftalion founded in 1964 and which became the cradle for the development of French heterodox perspectives (Monneau 2018), included permanent library space, some academic positions, and a scholarly journal. Dekker and Kuchař (2021) describe the output of the Ostrom workshop, which was de facto a kind of research center, as including artefacts such as databases, and facilities, such as libraries. ${ }^{7}$

The "sending out" type of events usually took place every year, are big and open, lasted a few days and was primarily aimed at publicizing and disseminating ideas, theories and tools, as well as networking. The "bringing in" type often featured a smaller set of invited participants, or at least speakers, with or without an audience. Perhaps because of the costs of travelling to sometimes remote locations, those gatherings lasted no less than a week, often several ones and were rather meant at building concepts, practices, intellectual or political agendas. Yet other workshops or seminars were held locally with some regular frequency, for instance weekly or monthly, on the usual worksite of participants. In spite of commonalities, their purposes were quite different, spanning the training of students into applying tools, concepts and methods, the production of new knowledge through aggregation, i.e., converging toward joint definitions, or disaggregation, i.e., investigating new social issues where theories

\footnotetext{
${ }^{7}$ Locher $(2018,548-9)$ likewise insists on the large paper and digital databases of US city services that were produced alongside the work of those who participated in the Ostrom Workshop, and in particular its field studies of the provision of police services in urban areas, in the 1970s. He describes the workshop as a "center of calculation," to use Bruno Latour's wording.
} 
and tools can be applied. They sometimes aimed at both, and there is no systematic relationship between aims and characteristics. For instance, the 1947 Mont Pelerin Society conference spanned two weeks. The program of the first one had been thought in advance by Friedrich Hayek, and it was aimed at the production of a joint statement to guide an activist liberal policy in the modern world. But the second week was programmed in situ by the participants, and featured sessions on topic ranging from agricultural policy to nuclear war, and poverty. Intended output can also explicitly include a book (as in the case of the Cambridge seminar on trust), a set of papers, a set of comptes rendus, a common statement, a journal, a network (as in the case of ISoM) or future positions. The séminaire Aftalion, Monneau (2018) explains, was geared toward helping young heterodox economists to succeed in the Concours de l'Agrégation, the national contest allowing French economists to obtain full-professorship. Boettke, Marciano and Stein (2021) mention sharing a "perspective," creating a "community of discourses" and even creating an "atmosphere" as goal that Buchanan had on his mind when establishing the Virginia workshop in political economy in the 1950s.

But these events also result in a host of by-products, from friendships and enmities to hierarchies and cultures of debate, disagreement and consensus. These may be tied to the rules of each event: are participants local only or is an external speaker invited? Is participation based on invitation, application, institutional affiliation, sponsoring from existing members? Can audience freely attend? Do students or professors ask questions first? Does the speaker present some research or merely respond to criticisms, comments and questions? Are presenters paid, as in the case of Cowles Summer conferences? Who discusses papers? Delving into the details of these events is a first way to study them, one static. It can serve two historiographical purposes, sometimes intertwined. SCOWs can be studied on their own terms, to answer the question: how have conferences, seminars and workshops contributed to the history of economics, the development of new theories, the spread of models and tools, the dominance and marginalization of some intellectual agendas and communities. What do they do? What do they produce? But some authors in these issues also use SCOWs as telescopes to zoom onto the dynamics of a field, or the interactions between key protagonists or the debates surrounding a new practice at a given point in time (Innset, this volume, see also Goutsmedt 2017). For SCoWs are formal representations of informal links, power structures and intellectual rivalries and hierarchies.

Several articles also study SCoWs in a more dynamic fashion. This involves not only the study of a series of conference or workshops, but also of what happens before these, aka departmental debates, grant application, invitation, during the event, on the side (travels, lunches and dinners, entertainment) and afterward (publication of proceedings, establishment of a society, etc.) Considering SCOWs, not just as standalone events, but also as processes helps understand how new theories, practices, agendas and communities emerge, spread, consolidate or get marginalized. Goutsmedt, Renault and Sergi (2021), for instance, argue that the programs of ISoM conferences both contributed and reflected the growing marginalization of European disequilibrium theories in the 1980s.

\section{Bringing in: conferences, workshops and seminars as construction sites}

What economists intended to build through organizing SCoWs is extremely diverse. It included theories, concepts, but also tools and practices, intellectual, policy and political programs, as well as institutional spaces, networks and communities. They did so by gathering people and resources in specific places and times and structuring interactions. 


\section{Building concepts and theories}

Though perhaps the most obvious product of scientific SCoWs, concepts and theories were not the primary output that economists intended to produce. This may reflect a belief that these are best produced through individual inquiry, a belief in wide currency at least from the 1930s to 1980s. Our papers nevertheless highlight various types of theory building. Though trained as a sociologist, Gambetta wanted to pin rational choice theorists' attention to a concept hitherto the province of sociologists: trust. One outcome was Partha Dasgupta's famous paper on "Trust as a Commodity", which defined trust as a subjective probability. Gambetta's own paper on "Can We Trust Trust" discussed trust as a relation between two persons (or groups). These contributions allowed game theorists and experimental economists to seize the concept and discuss whether calculative trust was an oxymoron or how to study trust games in the lab. These definitions were refined through exchanges between rational economists of the Dasgupta and Thomas Schelling types, philosopher Bernard Williams, social psychologist David Good, social anthropologist Ernest Gellner, or political scientist John Dunn, among others (Camilotto 2021).

Conversely, both Mincer and Becker had already matured how the concept of human capital reshaped theories of income inequalities, education, or the household. Their agenda was to help their students expand the range of theoretical and empirical applications of human capital theory. Students focused on employment opportunities for African-Americans, Asians, Jewish communities or women, and wage differentials in the military, tried to understand earning profiles over the life-cycle and across genders, or the role of firm-specific training (Texeira 2021). The institutions that Buchanan, Rutledge Vining, Warren Nutter and Ronald Coase, among others, built at the University of Virginia, then Virginia Polytech Institute, relied on stacking workshops, seminars and conferences. "It was a perpetual workshop environment," Boettke, Marciano and Stein note. Each had a distinct purpose, but some were "Bush-like seminar workshops," to use Buchanan's own words, designed to support a cumulative process of generating knowledge. They were named after his colleague, the late Winston Bush, who had organized a workshop in which all participants were tasked to write papers on the same topic, anarchy. Through combining workshops and topical one-shot on-site conferences with an ambitious visiting program to bring fellow travelers in, Virginia economists sought to develop their general idea that economists needed to research more systematically actual institutions for collective decision-making. Public Finance; the pricing of public goods; bureaucracy; federal fiscal responsibility; constitutional choice: the topics of special workshops and conferences always fitted Buchanan's interests, but the events were conceived in a way that his students and colleagues would produce independent research, some that helped him refine his own theories. Yoking together year-long seminars, a visiting scholar program and one-site conferences was also what enabled the Ostrom workshop, conceived as a "team," to draw on the field work of its members to produce a joint analysis of the governance of policy bodies, common property and knowledge commons. Core concepts of common pool resources and polycentricity came out of this joint effort. From the 1960s onwards, several district Reserve Banks of the Federal reserve system sponsored thematic conferences in macroeconomics: famous examples include the 1978 conference titled "After the Phillips Curve: the Persistence of High Inflation and High Unemployment" (Goutsmedt 2017) or the one that John Kareken and Neil Wallace organized at the Federal Bank of Minneapolis later that year to rethink monetary models. Like the conference on "Microeconomic Foundations of employment and Inflation Theory" that Edmund Phelps organized at Penn in 1969, these events did not allow macroeconomists to agree on specific theories and models, but rather to focus on common 
topics, to articulate their disagreements on the uses of macroeconometric models, the nature of modeling of money, or the shape of expectations, and to produce landmark articles and books. ${ }^{8}$

\section{Building tools, practices, epistemologies and standards}

But SCoWs were the crucible to more than concepts and theories. Some were organized by groups of scholars who recognized that they shared a common vision of what economic knowledge and practices should look like, found them in minority, and wanted to achieve a critical mass so at to mature such epistemologies: the Virginia political economists challenged the formalized theories of collective decisions and public goods proposed by Kenneth Arrow and Paul Samuelson; they wanted to build "a community of thought." The scholars assembled around the Ostroms heralded a cross-fertilization of methods taken from political sciences and economics that was increasingly pushed to the boundaries of the discipline in the 1970s. They explicitly chased "common foundations for intellectual dialogue," one that was achieved through coining the Institutional Analysis and Development framework in the next decades. When the Cowles Commission began its summer workshop, it was the combination of mathematic techniques and statistics for theoretical and empirical work that its members promoted that was a minority view (Dimand 2021, this volume). It still was when Tjalling Koopmans, Harold Kuhn, George Dantzig, Albert Tucker, Oskar Morgenstern and Wassily Leontief organized a Cowles conference in Activity Analysis of Production and Allocation in the summer of 1949. Till Düppe and Roy Weintraub (2014) insist that the conference "was not intended....as a pathbreaking event," but rather as a coming together of individuals who all took "mathematical values of rigor and axiomatization for granted," and shared, Debreu remembered, an "enthusiasm for convexity analysis." The conference was not just the cradle for a host of new tools, including linear programming, game theory, operation research, the uses of convex sets, separating hyperplanes and fixed-point theory, but the "birth of an epistemic community." Likewise, devoting whole morning to discussing a single paper during the Cowles summer conferences, as well as published summaries of the papers, allowed tools like general equilibrium analysis or statistical testing of dynamic systems to become entrenched in a community that included academic and private sector economists (Dimand 2021).

Gambetta's Trust workshop provided a space whereby sociologist grew more familiar toward game theory tools and Chicago workshops were conceived as labs where students learned how to apply the tools of price theory, i.e., learned a set of practices. Because many of these SCoWs were fueled by shared epistemologies, they also contributed to produce standards. The dissemination of "American standards" for macroeconomic research was an explicit purpose of those European economists who participated in the ISoM. Some of them had assimilated said standards throughout their own graduate studies in the US. That SCoWs were perceived as engines for the Americanization of science was not specific to economics. Another example is offered by Thibaud Boncourt (2011). He documents how the conferences sponsored by the International Political Science Association and the European Consortium for Political Research, born 1947 and 1970 respectively, contributed to disseminate American standards for political science in Europe.

\section{Building programs, spaces, networks and communities}

\footnotetext{
${ }^{8}$ The organization of thematic annual conferences at Duke University since 1989 is also seen as a way to nurture a collective effort to shift the boundaries of history of economics. Their proceedings are published in a special volume of History of Political Economy every year (Giraud 2019, 634-638)
} 
Our set of papers document further intended outcomes underpinning the organization of SCoWs. These included dissertations (Columbia and the Ostrom Workshop), atmospheres (Virginia), governance rules that were co-constructed with policy actors (Ostrom workshop), as well as intellectual and political agendas that were often entrenched in societies and journals. This was the case not only of the Mont Pelerin Society, but also of the many professional societies that were established after "founding" conferences. That opening new intellectual and institutional spaces, building networks and communities were explicit goals or crucial byproducts of many of these conferences is seen in the title of our articles: VPI political economists "never walk[ed] alone", the Mont Pelerin Society fostered "an army of fighters," the Columbia Labor Workshop nurtured an "intellectual community," a term also present in Dimand's paper on the Cowles summer conferences.

Through several of these communities grew out of student training (see next section), it is striking that they were not brought together through achieving some consensus. Consensus is generally not among the products of conferences. Quite the contrary. As pointed out by historians of science, conferences often foreground, even stage, disagreements or rivalries, in economics as in other sciences. ${ }^{9}$ As disagreements over the interpretation of quantum theory reached a climax in the final sessions of the 1927 Solvay conference, Austrian physicist Paul Ehrenfest walked to the blackboard and captured the general confusion through writing down a famous biblical quote:

"And they said one to another: Go to, let us build us a tower, whose top may reach unto heaven; and let us make us a name. And the Lord said: Go to, let us go down, and there confound their language, that they may not understand one another's speech."

The 1958 Dartmouth conference on artificial intelligence was designed to bring to the table proponents of computer-brain and computer-mind modeling metaphors in cybernetics, but several of them did not even attend the conference (Kline 2011). The most famous conferences are remembered from the theoretical, empirical or generational clashes they involved. Goustmedt's 2017 study of the 1978 conference organized by the Federal Bank of Boston emphasizes the diverging explanations for stagflation and the disappearance of the Phillips curve proposed at the time, and how these were used as a footboard to err more fundamental methodological disagreement. It was the conference where Robert Lucas and Thomas Sargent presented their famous paper "After Keynesian macroeconomics", in which macroeconometric modeling of the Cowles types is repeatedly called a failure. ${ }^{10}$

\footnotetext{
${ }^{9}$ Key disagreements were settled outside SCoWs. A famous example derives from Coase's 1959 argument that, under certain conditions, externalities could be internalized via negotiation, was disputed by economists at the University of Chicago. When George Stigler asked Coase to present a paper at Chicago's Industrial Organization workshop, Coase agreed to do so, but only on the condition that he would also be afforded the opportunity to defend his externalities argument. That now-legendary defense took place at the home of Aaron Director on the night before Coase's workshop presentation and, as McCloskey tells the story, included the shuffling around of chairs to represent changes in property rights (see Medema 2021). Boettke et al. (2021) likewise explain that Coase's 1960 paper was discussed, not in formal a seminar, but during an informal dinner of the UVA Political Economy Club

${ }^{10}$ See also Denord (2001) on the 1938 Colloque Walter Lippmann. Denord explains how the common agenda du liberalisme outlined by Lippmann at the end of the conference was general enough to accommodate sharp disagreements over how to define and renew said political philosophy. The Money Study Group, founded by UKbased economists Harry Johnson, David Laidler, Michael Parkin and Bob Nobay in 1970 combined seminars and conference. It was intended as a "forum for debates on monetary policy" that brought together academics, policymakers and practitionners (Chrystal and Capie 2020, 16)
} 
A core feature of SCoWs is thus the debating cultures they nurture and disseminate. Much has been written about the Chicago culture, in particular as sustained in Milton Friedman's Money and Banking workshop and George Stigler's Industrial Organization workshop. Dekker and Kuchař paint a picture of a reflexive process whereby the Ostroms drew on their own research on governance to shape a "constructive" culture in which inside and outside contestation, as well as suggestions for extensions of their intellectual framework were welcomed. ${ }^{11}$ At Chicago, antagonism and dissent were solved through criticisms. McCloskey (quoted in Emmett 2011) describes a process of "finding where the bodies are buried." It gave Chicago workshops a reputation for chewing up visitors. ${ }^{12}$ The extent to which such Chicago culture was subsequently exported to other workshops, in particular in macroeconomics, is a question worth further investigation. Chicago was not the only site where such debating culture developed. At Harvard, economic historian Alexander Gerschenkron found that "lectures are the Middle Ages...it's not an adult way" (Dawidoff 2002, 251-252). He wanted his students to "ready themselves for a provocative group conversation" because he felt that "the need to articulate his opinion and to defend it against the other students and the instructor, are things that are likely to continue to ferment and are not easily forgotten." He thus organized a weekly graduate seminar where 8 to 12 students gathers to discussed a paper. These students remember the "dogfight" and "intellectual free-for-all" atmosphere: "“it was just us... so we could be completely open and we didn't we needed to be polite. We were very hard on each other," one remembers. Cultures are not the only element that traveled through SCoWs. Beyond building, they have largely been geared toward disseminating.

\section{Sending out: seminars, conferences and workshops as weapons of dissemination}

\section{Convincing}

The first type of public targeted by SCoWs, as highlighted in most accounts in these volumes, was graduate students. Even before being trained to apply concepts, theories and tools, they had to be seduced. Becker and Mincer founded their labor workshop at a time when human capital, time allocation and household economics were not popular topics, Teixeira (2021) explains. The pair conceived the venue as a way to attract the first-rate graduate students that Becker later explained were the major reason behind the spread of human capital theory. Karl Shell also confessed becoming enticed by mathematical growth theory through attending the Stanford workshop on mathematical economics and econometrics run by Arrow and Marc Nerlove as a student (Spear and Wright 2000, 704). Several contributions to these twin issues describe workshops as primarily conceived as training devices for graduate students. Their leaders drew upon the ecclesial tradition of disciples learning the gospel and the workshop tradition of apprentices learning by doing. Imitation, then a certain degree of autonomy and originality were expected from students through "pressuring" and "monitoring" them and exposing their work

\footnotetext{
${ }^{11}$ How the other workshops and seminars surveyed in our special issues accommodated dissent is difficult to recover. This would require researching which visiting scholars or colleagues were not invited to routine or important events.

${ }^{12}$ Harold Demsetz reported that a visiting scholar once asked Stigler at the luncheon before his presentation where he should present his paper from (meaning whether he would be expected to stand at a podium or sit at a desk). Stigler's response was: "in your case, you will probably want to present from underneath the desk" (Emmett 2011, 111). Harberger (2021) recently insisted that his Public Finance workshop "was different from Milton's in the sense that I gave much more freedom to people, and so I have very good students." See also Gindis (2020) on the cold reception Jensen and Meckling encountered in Chicago and Rochester finance workshops in the 1970s.
} 
to peer and senior criticisms and/or suggestions. Teixeira (2021) quotes former Columbia student Arlee Leibowitz describing this successful socialization: "we had the same training, we had the same understanding of things, how to read the world, and thus discussions could begin without a preface." Trained students in turn became agents of dissemination, for instane through presenting at larger outside conferences (Boettke et alii, next volume). Both the blue-covered Cowles working papers and the yellow-paper)covered printed NBER working papers, launched in 1973, may have contributed to the dissemination of research in economics, within and beyond academia.

Colleagues learned about the relevance of an approach or of the usefulness of a tool or a concept either through being invited for a short conference or a longer stay to the SCoW site, or through attending a session elsewhere. In the 1930s or 1950s, reproducing research papers was expensive, access to and even knowledge of new research was therefore much more difficult than today. The circulation of discussion papers in advanced of department and Cowles research meetings at Chicago as soon as the 1950s was a luxury (Hildreth 1985, 6).

During conferences and workshops alike, convincing other economists was achieved either through flaunting consensus, or through airing disagreement, thus competition. Virginia economists coupled in-house SCoWs with carefully designed sessions at the AEA or the Southern Economic Association. These would typically include a senior, a student and a fellow traveler sharing a political economy approach to a given topic. It was thus convergence rather than dissent that was showcased. Conversely, the many histories of the rise of new classical macroeconomists testify to the systematic choice of organizing confrontations, or at least perceiving them as battlegrounds. ${ }^{13}$ The Ostroms had shaped their approach to the governance of institutions in opposition to Gareth Hardin's 1968 conclusion that common resources would be depleted as population grows. They did not shy away from confronting his views in correspondence, print or conferences. The ISoM organizers chose to select seven papers to be presented each year, and to have them discussed by a US and a European scholar. The Cowles summer conferences combined scientific sessions where, it was not rare, a senior scholar like Ronald Fisher or a rising star like Haavelmo or Samuelson lectured several days in a row to conference participants, and public lectures with greater local public attendance (Dimand 2021, next volume). Guests from the local civil society were attracted through visits at the Colorado Springs Fine at Centers or Alfred Cowles' own residence, motor trips, hikes or picnic suppers.

\section{Stabilizing}

The rules underpinning various SCoWs may have been diverse. They nonetheless served not just to produce concepts, theories, tools and approaches and disseminate them. SCoWs also stabilized them through ensuring that their production and refinement became embedded in permanent institutions and that their use was standardized. This involved engaging in gatekeeping and building hierarchies. SCoWs indeed both created and perpetuated all sorts of hierarchies, often reinforcing each other: intellectual, age, class, geographical and gender. In his contribution, Innset asks whether the rather homogenous wealthy social background of participants to the Mont Pelerin Society conference determined its success. ${ }^{14}$ The workshop

\footnotetext{
${ }^{13}$ In an autobiographical essay, for instance, Robert Lucas (2001) described a 1978 Boston Fed conference as pitching "the Keynesian establishment" and the "'new classical' rebels," with a "chaotic" question series that ended up with the "triumph" of the later.

${ }^{14} \mathrm{He}$ acknowledged that US participants were of more diverse social backgrounds and point to some exceptions, like Maurice Allais, among the European casting as well.
} 
system that Lewis, Schultz and Jonhson conceive at Chicago was one in which a senior often charismatic white male scholar ran his group, in a way reminiscent of medieval master craftsmen. Their status is acquired not through religious belief or craft, but intellectual mastery. The hierarchy is then enforced through rules set up, but also spatial or food arrangements.

Across SCoWs, leadership assumed very diverse forms and created different dynamics. At Chicago, convincing the audience of many workshops meant convincing Milton Friedman, so much so that the department was considered as a "fortress built around Milton Friedman and his views" (Harberger and Edwards 2021, 11; see also Medema 2021). Buchanan's vision was equally central to the Virginia ecosystem. The Ostroms wanted to foster collaboration among equals, but they were also considered master craftsmen. Of his Stanford student days, Cass remembers that Uzawa treated graduate students as equals (in Spears and Wright 1998, 534536). More generally, who get to speak first and when, how are participants and speakers seated are still under-documented elements of SCoWs history, but they represent promising lines of investigation. ${ }^{15}$ The spatial embodiment of leadership matters. Dekker and Kuchař mention that initially, the seminar room of the Ostrom Workshop used to be a former dining room, so that all participants would sit around a large table. Teixeira contrasts the leading role of Becker, siting in the front row, asking questions and calling on students to do so, and Mincer, in the back, raising few but important points at the end of seminars. ${ }^{16}$

The role of food and drinks, if not articulated, surfaces in almost every contribution. As famously emphasized by Claude Levi-Strauss in Le Cru et le Cuit (1964), food is both an engine for inclusion and sorting. Students bonded together through brown bag lunches at Columbia, or "mandatory after-seminar beer drinking at the Oasis" in Stanford (Shell in Spears and Wright 2001, 705). Students and faculty sometimes share food, but only selected faculty are invited to pre-workshop dinners at Chicago or dinners of the Political Economy Club of Virginia. Camilotto (2021) documents how "lunch is a major structuring event in life at Kings," where yo could make good impression. Dinner is shared among college Fellows, who often belong to other disciplines. Discussions start in seminars, continue in drink receptions, end at the pub. Though monetary economist Irving Fisher was established enough so that his ascetic regimen could not exclude him from the community of economists, it was nevertheless a subject of joke. ${ }^{17}$ The contribution of food in establishing gender and class hierarchies is best encapsulated in a memory unearthed by Innset: young British economist Dorothy Hahn, one of very few women present at the 1947 Mont Pelerin Society, traveled to the Hotel du Parc as Hayek's secretary. Presented with an orange, a rare treat in a war-devastated Europe, she did not understand how to eat it. She recalls the embarrassment of having Hayek peel it for her.

\section{Mainstreaming}

Once disseminated and stabilized, the theories, practices, tools, approaches produced within SCoWs could then be either mainstreamed, aka made a permanent component of the body of

\footnotetext{
${ }^{15}$ Some sitting maps can be found in the archives of the Bank of England, suggesting that planning for spatial interactions was carefully thought in advance of conferences and panels.

${ }^{16}$ See Grossbard (2001) on the importance of female students attending the workshop, unusual at the time, and the differences between female and male dissertation topics. She ties the lack of women attending Becker's subsequent Chicago workshops to his emphasis of natural grounds for existing gender-based division of labor in his 1970s and 1980s writings.

${ }^{17}$ In a tribute given to celebrate what would have been Fisher's $100^{\text {th }}$ birth anniversary, Samuelson remembered Fisher's seventy-fifth birthday: "If memory serves, our guest of honour was indulgent and the cocktails were delicious. (Lest I be accused of a credibility gap, let me hasten to add that the guest was indulgent, not indulging: it was our cocktails that were delicious; I cannot speak for Fisher's tomato juice!' (in Fellner 1968, 36-37).
} 
economics, or marginalized. Again, SCoWs both contribute to and manifest these processes. The mainstreamization of US macroeconomic models in Europe are seen in the replacement of ISoM founders with a new generation of European macroeconomists who either operated from the US like Olivier Blanchard or who were strongly embedded in US networks (Charles Bean, Richard Baldwin, Christopher Pissarides, Richard Portes). This went hand in hand with the marginalization of European disequilibrium theory, which gradually disappeared from ISoM programs. The IsoM also became embedded in a wider European dynamics characterized by the establishment of the European Economic Association and the Center for Economic Policy Research.

But the most powerful representation of mainstreaming and marginalization is offered by the AEA/ASSA annual meeting, held in a major US city every first week-end of January. David Warsh (2006) describes this giant fair where new models, tools, approaches and hierarchies are showcased through star panels, presidential addresses, prize announcements and thousands of sessions: "great intrigues are plotted behind the scenes beforehand, then unfold in public with barely a clue as to the identity of the mugger and the muggee. Rank and privilege are all clearly understood by the initiates: there are very few disruptions, except for the occasional quack," he writes. He then carefully describes the interactions he witnessed during a 1996 session on "New Growth Theory and Economic History: Match or Mismatch" as an introduction to his book narrating how economists, in particular Paul Romer, have rethought growth in the 20th century. But the AEA annual meetings are themselves instruments of the mainstreamization process. Attendance at each session is carefully counted, and the count determines how many sessions each society or field specialty can claim the following years. "Loosing" a session is therefore a permanent source of worry for the less prestigious fields. The role of major conference in representing, perpetuating and shifting established hierarchies was understood by organizers. The guidelines drafted by agricultural economist and econometrician Marc Nerlove are telling in this respect. Tasked with assembling the program of the Econometric Society Winter meeting of 1961, he outlined four potentially conflicting criteria for participant selection (by order of importance): "a) coverage of major research centers; b) geographical dispersion; c) diversity of fields; d) lack of previous service." He proceeded to classify US research centers in 9 geographical eras. He recommended to include first rate papers but noted that they were rare. They should be combined with younger authors who had not yet participated in other meetings. However, he noted, organizers should "try to beef up sessions with relatively unknown people by choosing big guns as chairmen and/or discussants." 18

As we previously argued, SCoWs hardly produce consensus on theories, tools and practices. But taken together, they sometimes curate disagreements through partitioning the institutional and intellectual space in a way that mainstreamed the respective approaches advanced. In the 1960s, the still fragile field of French economics became entrenched in 3 seminars, each supporting different methodological, theoretical and ideological orientations (Le Merrer 2011). Alongside the aforementioned Séminaire Aftalion housing heterodox perspectives, the Jean-Baptiste Say theory seminar led by Daniel Pilisi discussed Anglo-Saxon theories, while the Goetz-Girey seminar focused on policy-related knowledge and the relationships with psychology and sociology. Macroeconomist Robert Gordon $(1989,181)$ likewise remarked that the 1980s US macroeconomics ecosystem was slip up among three groups that were each represented by a ScoW series:

\footnotetext{
${ }^{18}$ Box 172, folder Program Committee - 1961, Nerlove archives, Rubinstein Library, Duke University
} 
"On the left, we have the Brookings Papers on Economic Activity ( BPEA) ... This group is and always was Keynesian, so much so that Barro, Lucas, Prescott, and Wallace have never been invited to a single meeting of the 47 which have been held over the last 19 years. On the right. we have the Carnegie-Rochester conference series (CRCS) ... which has cast a wider net than BPEA and has been particularly hospitable to the research of the fresh water macroeconomists. In the middle we have the NBER research group on macroeconomics, admirably run by Robert Hall to include new classicals and new Keynesians alike."

\section{Challenging}

While SCoWs therefore fuel and perpetuate pecking orders within the discipline, the case studies hitherto covered reveal that have also been used to challenge existing hierarchies, intellectual or social. They have sometimes been instruments of generational shifts. Workshops and seminars existed at Columbia long before the Becker-Mincer labor workshop, for instance. In 1932, graduate students convinced the then prestigious cast of economics professors (Mitchell, Clark, Angell) to offer a seminar on economic theory. While Mitchell recognized the benefits of the new format, Eli Ginzberg $(1990,16)$ relates that "in the second year of the seminar J. M. [Clark] had sat through his entire block of sessions without having opened his mouth. It was his wont to leave a few minutes early to catch the last train to Westport. At the close of his last session, with his hand on the knob, he finally muttered: 'Well, you never can be sure what comes out of sessions like these-good night.",

SCoWs also made geographical hierarchies visible, and, together with the creation of new societies, helped challenge them. The European Historical Economics Society and associated annual conferences were founded in 1991 as a reaction to the perceived dominance of American scholars, topics and data in economic history, Karl Gunnar Persson reminisces. ${ }^{19}$ The impetus came from the Second World Congress of the Cliometric Society, held in 1989 in Madrid: "There were lots of good papers but rather too much self-affirmative action on the side of the US participants, some of whom displayed a supreme ignorance of what European economic historians had accomplished in the past and scant interest in what they did at present. The idea of having the Congress in Europe was meant to give a stimulus to European quantitative economic history, but most Europeans were out-smarted by the numerous North Americans whose debating culture was not very helpful," Persson explains.

Finally, the path toward a gender reckoning in the economics profession included amending the program of the AEA/ASSA annual meeting (Chassonnery-Zaïgouche, Cherrier and Singleton 2020). As soon as the caucus of women economics had established the Committee for the Status of Women in the Economic Profession in 1971, they campaign to then AEA president Arrow for greater inclusion of female economists in the program. When Arrow explained that he was willing to do so but that women economists were hard to find, CSWEP president Carolyn Shaw Bell sent a list of a hundred names. Such listing was subsequently enlarged into a permanent roster. The CSWEP campaign for better representation of women in economics later included pointing to Martin Feldstein, the president of the NBER, that none of the 57 officers and directors of the NBER, considered as a permanent research workshop, was a woman and that recent sponsored research on family had been conducted by 10 men.

19 The history of the EHES society is taken from its website: http://www.ehes.org/history.html (accessed $05 / 17 / 2021)$ 


\section{Conclusion: explaining success and failures?}

The seven contributions of these twin issues thus offer a diverse set of case studies allowing to document the role of SCoWs in the history of economics. They together emphasize their key role in producing, disseminating and stabilizing concepts, theories, tools, approaches and epistemologies, but also artifacts, cultures and hierarchies. They also point to further dimensions to be explored, such as the role of rules, spatial arrangements and food in the intellectual and social fabric of the discipline. Finally, without proposing a definitive answer, these contributions point to ways to define and explain the successes and failures of these scientific endeavors. Two types of protagonists are systematically emphasized: leaders and entrepreneurs. The leaders (the Ostroms, Buchanan, Hayek, Becker and Mincer), who carry an intellectual, political or policy agenda forward, steal the show. Individual charisma is also emphasized in other seminar accounts. Gerschenkron's biographer and grandson, Nicholas Dawidoff $(2002 ; 252-255)$ collected testimonies of former participants to the Harvard economic history workshop in the 1960s: "tremendous influence... he was not a cliometrician and he trained the world's best cliometricians," "he created a sense of high purpose we all felt. There was a scholarly standard... he was an exemplar of intellectual inquiry... the man was a presence." ${ }^{20}$ However, leadership is a two-ways street. What needs to be unpacked is not just why these individuals assume leadership, but also how their colleagues and students entrusted them with it. Doing so would help unpack the tensions between authority, autonomy and originality emphasized by Sennett in his history of craft workshops and how these were solved. How much originality did such workshops fostered? Were students encourage to break with existing methods and wisdom?

All case studies also highlight the role played by economists, businessmen or benefactors less intellectually dominant, but no less important: Alfred Cowles who, as Belgian industrial chemist Ernest Solvay had done a decade before, funded the Commission, the summer conferences and a journal, Econometrica. He became secretary of the association. Swiss Finance businessman Albert Hunold who raised funding from Credit Suisse, became secretary of the society and editor of its journal. Schultz, who "sells" the Chicago workshop system to the Ford and Rockefeller foundation and secure the funding to entrench it. ${ }^{21}$ Macroeconometrician Georges de Menil, whose institution building acumen and vision for European macroeconomics proved more influential than his intellectual contributions. The visions and money of these entrepreneurs shaped, not so much the content, but rather the institutional structure and resilience/persistence of seminars, workshops and conferences. For a

\footnotetext{
${ }^{20}$ Most students emphasized Gerschenkron's silence, the way he only offered "succinct,"often "delphic" comments at the end of a session: "if you had a tape recorder, you'd find he says very little," a student remembers. "Reactions from him were so rare that the students spent hours trying to interpret the sparse flickers and nods he gave them," Dawidoff concludes. They also emphasized the mysterious character of Gerschenkron's leadership: "by a process I still don't understand, the man set an elevated critical tone that prevailed;" "I've never been able to explain how somebody could come into that seminar room and could be of such tremendous influence without using his own work as a guide" (Dawidoff, 2002, 250-255)

${ }^{21}$ The price of airfare tickets (or sea journeys before that), as well as reproduction costs made a steady source of money all the more important.
} 
failed conference, workshop or seminars, to begin with, is one that for lack of funding, did not take place.

\section{References}

Adams, Herbert, 1884. New methods of Study in History. The John Hopkins University studies in historical and political science.

Ash, E. Chen, D. Naidu, S. 2018: "Ideas have consequences: the impact of law \& economics on American Justice" https://elliottash.com/wp-content/uploads/2018/08/ash-chen-naidu-2018-07-15.pdf

Bacciagaluppi, Valentini, 2009. Quantum Theory at the Crossroads: Reconsidering the 1927 Solvay Conference. Cambridge: Cambridge University Press.

Backhouse, Roger. 1997. "The Changing Character of British Economics." History of Political Economy 28(Supp), 33-60

Boettke, Marciano, Stein, 2021. "They never walked alone. Workshops, seminars, conferences and the making of Virginia Political Economy." Revue d'Economy Politique, Fall, forthcoming.

Camilotto, Nicolas. 2021. "From multidisciplinarity to interdisciplinarity: on the role of the seminar as an interface for exchange. The case of the Seminar on Trust and Social change (1985-1986)," Revue d'Economy Politique, Fall, forthcoming.

Chassonnery-Zaïgouche, Cherrier and Singleton 2020. "'Economics is Not a Man's Field': CSWEP and the First Gender Reckoning in Economics (1971-1991).” Working paper

Chrystal, Alex; Cape, Forrest. 2020. "The Money Study Group (MSG) at fifty: Twenty years of the MSG and another thirty of the Money, Macro, Finance Research Group (MMF)." The Manchester School, 1-17.

Coats, A.W. 1961. "The Political Economy Club: A Neglected Episode in American Economic Thought." The American Economic Review 51(4), 624-637.

Dawidoff, Nicholas, 2002. The Fly Swatter: How My Grandfather Made His Way in the World, Pantheon Books

Dekker, Kuchař 2021. "The Ostrom Workshop: Artisanship and Knowledge Commons." Revue d'Economie Politique, this volume.

Denord, François, 2001. «Aux origines du néo-libéralisme en France : Louis Rougier et le Colloque Walter Lippmann de 1938.» Le Mouvement Social 195 
Dimand, Robert, 2021. "The Cowles Summer Research Conferences on Economics and Statistics 1935-1940: Building a Community for Mathematical Economics and Econometrics." Revue d'Economie Politique, Fall, forthcoming

Dupas, P. Modestino A.S., Niederle M., Wolfers Justin, and the Seminar Dynamics Collective. 2021. "Gender and the Dynamics of Economics Seminars," working paper, https://web.stanford.edu/ pdupas/Gender\&SeminarDynamics.pdf

Düppe, T. and Weintraub, E. R. 2014. Siting the New Economic Science : The Cowles Commission's Activity Analysis Conference of June 1949. Science in Context, 27(3):453-483

Emmett, R. 2011. "Sharpening Tools in the Workshop: The Workshop System and the Chicago School's Success" in Van Horn, Mirowski \& Stapleford (eds.), Building Chicago Economics. Cambridge University Press.

Fellner, William (ed). 1968. Ten Economic Studies in the Tradition of Irving Fisher. New York: John Wiley \& Sons, Inc.

Ginzberg, Eli. 1990. "Economics at Columbia: Recollections of the early 1930s." The American Economist. 14,19.

Giraud, Y. 2019. “Five Decades of HOPE.” History of Political Economy 51(4), 601-669

Gordon, Robert, 1989 [2007] "Fresh Water, Salt Water, and Other Macroeconomic Elixirs." Economic Record 65(2):177-184

Goutsmedt, A. 2017. Stagflation and the crossroad in macroeconomics : the struggle between structural and New Classical macroeconometrics. Documents de travail du Centre d'Economie de la Sorbonne

Goutsmedt, Sergi, Renault, 2021. "European Economics and the Early Years of the 'International Seminar on Macroeconomics'”, Revue d'Economie Politique, this volume

Grossbard, Shoshanna, 2001. «The New Home Economics at Columbia and Chicago", Feminist Economics 7(3), 103-130.

Harberger, Arnold. Edwards, Sebastian, 2021 (forth). "The Department of Economics at the University of Chicago, 1947-1982" in Cord (ed), The Palgrave Companion to Chicago Economics.

Heilbron, Johan 2006 [2020] La sociologie française. Sociogenèse d'une tradition nationale. Paris, CNRS, coll. « Culture \& société », traduit de l'anglais par Françoise Wirth

Henderson, James, P. 1983. "The oral tradition in British economics: influential economists in the Political Economy Club of London," History of Political Economy 15(2).

Hildreth, Clifford. 1985. "The Cowles Commission in Chicago, 1939-1955," working paper. 
Innset, 2021. "An army of fighters for freedom : The social environment of the first Mont Pelerin Society conference." Revue d'Economie Politique, Fall, forthcoming

Kempf, Christopher. 2020. "The Play's a Thing: The 47 Workshop and the "Crafting" of Creative Writing," American Literary History, 32 (2), 243-272.

Kline, Ronald. 2011. IEEE Anals of the History of Computing, 1058-6180/11, 5-16

Le Merrer, Pascal. 2011. "L'affirmation de l'économie comme discipline scientifique : une histoire française particulière.» Tracés. Revues de Sciences Humaines 11, 163-174.

Locher, Fabien, 2018. "Historicizing Elinor Ostrom: Urban Politics, International Development and Expertise in the US Context (1970-1990)," Theoretical Inquiries in Law 19(2), 533-558.

Lucas, Robert. 2001. "Professional Memoir," lecture given in the Nobel Economists Lecture Series at Trinity University, San Antonio, Texas

McCloskey, Deidre. 1992. "TEACHING:Alexander Gerschenkron." The American Scholar 61(2), 241-246.

Medema, Steven, 2021. "What Happened on Blackstone Avenue? Exorcising Coase Theorem Mythology," working paper.

Monneau, E. 2018. "Le séminaire comme dispositif collectif académique transitoire: Le cas du séminaire Aftalion en économie (1963-1974)” Raisons Politiques 2018/3, n71, 81-102

Sennett, R. 2008. The Craftsman. Yale : Yale University Press

Spears, Stephen E.; Wright, R. 1998. "An Interview with David Cass," Macroeconomic Dynamics 2, 533-558

Spears, Stephen E.; Wright, R. 2001. "An Interview with Karl Shell," Macroeconomic Dynamics 5, 701-741

Texeira, Pedro, 2021. "The Columbia Labor Workshop - The rise and decline of an intellectual community." Revue d'Economie Politique, this volume.

Warsh, David. 2006. Knowledge and the Wealth of Nations: A Story of Economic Discovery. WW Norton \& Co.

Winsor, Mary; Wilson, Leonard. 1999. "The Joint Atlantic Seminar in History of Biology." Isis 90(supp), S219-S225. 